\title{
Archaeological Monitoring of the HEB-GSA Parking Lot: Impacts to the San Pedro Acequia
}

\author{
I. Waynne Cox \\ Center for Archaeological Research \\ Brett A. Houk \\ Center for Archaeological Research
}

Follow this and additional works at: https://scholarworks.sfasu.edu/ita

Part of the American Material Culture Commons, Archaeological Anthropology Commons, Environmental Studies Commons, Other American Studies Commons, Other Arts and Humanities Commons, Other History of Art, Architecture, and Archaeology Commons, and the United States History Commons

Tell us how this article helped you.

This Article is brought to you for free and open access by the Center for Regional Heritage Research at SFA ScholarWorks. It has been accepted for inclusion in Index of Texas Archaeology: Open Access Gray Literature from the Lone Star State by an authorized editor of SFA ScholarWorks. For more information, please contact cdsscholarworks@sfasu.edu. 


\section{Archaeological Monitoring of the HEB-GSA Parking Lot: Impacts to the San Pedro Acequia}

\section{Creative Commons License}

\section{(c) (1) (8)}

This work is licensed under a Creative Commons Attribution-NonCommercial 4.0 International License 


\title{
Arrolhaedlogical Monitoring of the $\mathbb{H} \mathbb{E} B=G S A$ Parrking Lita \\ Impacts to the San $\mathbb{P}_{\text {edlro }}$ Acequuira
}

\section{Waynne Cox and Brett A. Houk}

\author{
Robert J. Hard and C. Britt Bousman \\ Prinicipal Investigators
}

Center for Archaeological Research The University of Texas at San Antonio Archaeological Survey Report, No. 279 1998

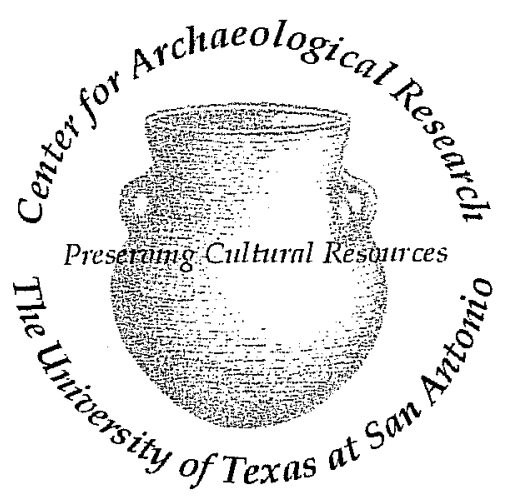





\title{
Archaeological Monitoring of the HEB-GSA Parking Lot: Impacts to the San Pedro Acequia
}

\author{
I. Waynne Cox and Brett A. Houk
}

Robert J. Hard and C. Britt Bousman

Prinicipal Investigators

Ccopyright 1998

Center for Archaeological Research

The University of Texas at San Antonio

Archaeological Survey Report, No. 279 
The following information is provided in accordance with the General Rules of Practice and Procedure, Chapter 41.11 (Investigative Reports), Texas Antiquities Committee:

1. Type of investigation: Monitoring

2. Project name: HEB-GSA Parking Lot

3. County: Bexar

4. Principal investigator: Robert J. Hard and C. Britt Bousman

5. Name and location of sponsoring agency: H.E. Butt Grocery Co., 646 South Main Avenue, San Antonio, Texas 78204

6. Texas Antiquities Permit No.: n/a

7. Published by the Center for Archaeological Research, The University of Texas at San Antonio, 6900 N. Loop 1604 W., San Antonio, Texas 78249-0658, 1998

A list of publications offered by the Center for Archaeological Research is available. Call (210) 458-4378; write to the Center for Archaeological Research, The University of Texas at San Antonio, 6900 N. Loop 1604 W., San Antonio, Texas 78249-0658; e-mail to car@lonestar.utsa.edu; or visit CAR's web site at http://www.csbs.utsa.edu/research/car/index.htm. 


\begin{abstract}
In October, 1997, the Center for Archaeological Research of The Univeristy of Texas at San Antonio monitored parking lot construction activities at the Federal Center (41BX622), part of the old United States Arsenal, in downtown San Antonio, Texas. The new parking lot, being constructed by H. E. Butt Grocery Company on land leased from the General Services Adminstration, will impact a section of the San Pedro Acequia which runs beneath an existing parking lot in the same location. The monitoring of these activities documented two sections of the acequia and corrected previous projections of the acequia's route. It is CAR's recommendation that the monitoring and documentation project has mitigated any adverse effects to the acequia.
\end{abstract}




\section{Contents}

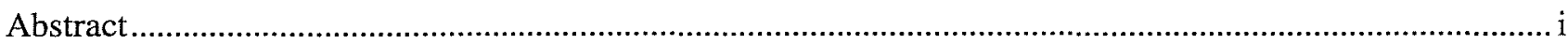

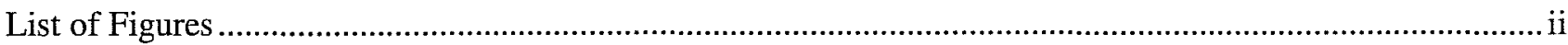

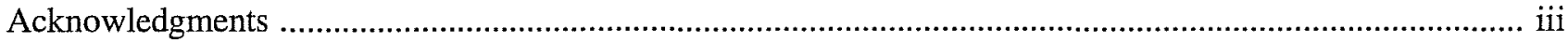

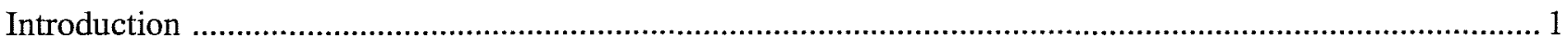

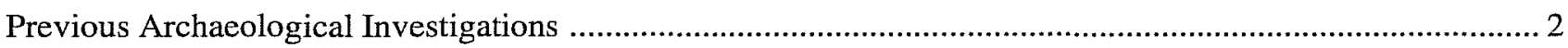

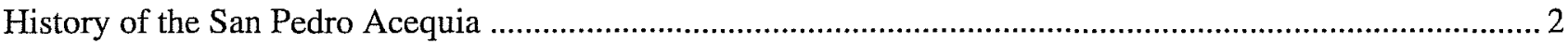

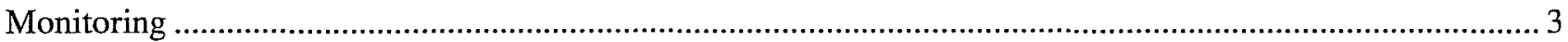

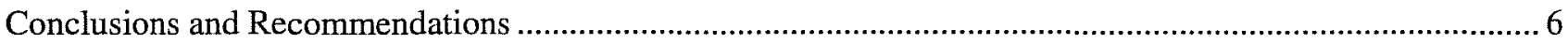

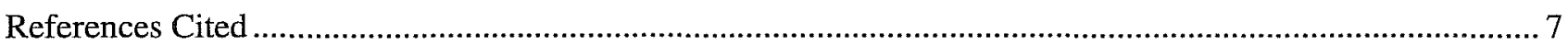

\section{Figures}

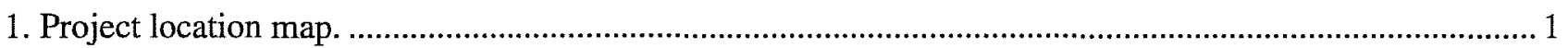

2. Map of project area with projected path of the San Pedro Acequia....................................................... 4

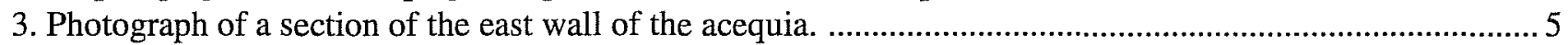

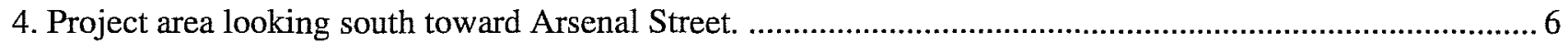




\section{Acknowledgments}

The Center for Archaeological Research (CAR) would like to thank Mr. David M. Quebedeaux of Pape-Dawson Engineers and Mr. Jan F. Michniewicz of H. E. Butt Grocery Company for their assistance with this project. The fieldwork was greatly facilitated by the cooperation of the personnel from Gates Construction and their subcontractors, who made every effort to insure that timely notification of their schedule was presented to the CAR representative. Not only did they insure that CAR was given full access to the site, but also made extra efforts to clear portions of the acequia to allow for proper documentation. 



\section{Introduction}

On September 25, 1997, Mr. Jan F. Michniewicz of H.E. Butt Grocery Company (HEB) contacted the Center for Archaeological Research (CAR) of The University of Texas at San Antonio (UTSA) and requested a proposal to conduct archaeological monitoring of parking lot construction activities at the corner of Arsenal and South Main streets in San Antonio (Figure 1). The project area is located within the boundaries of the Federal Center, a complex of eight buildings situated between South Flores Street on the west, South Main on the east, Arsenal Street on the south, and a line approximately $40 \mathrm{ft}$ north of Whitely Road on the north. The Federal Center was once part of the United States Arsenal which covered 25 acres and is listed as on the National Register of Historic Places. The Arsenal is also a City of San Antonio Landmark. The portion of the Arsenal bounded by the San Antonio River on the east, South Main on the west, Arsenal Street on the south, and Durango Boulevard on the north is designated
41BX622. The remaining area of the Arsenal is designated 41BX351 and is controlled by the San Antonio Parks and Recreation Department (Patterson 1997).

HEB has developed the eastern portion of the Arsenal as their corporate headquarters. The proposed outlease project will allow HEB to construct additional parking. The project involves the removal of an existing parking lot, the installation of subsurface electrical conduits, grading of the surface, and the installation of a new parking lot.

HEB is leasing this section of the Arsenal and Federal Center from the General Services Administration (GSA), and the existing parking lot covers a section of the San Pedro Acequia (Patterson 1997). Because the GSA is a federal agency, the project requires Section 106 clearance under the National Historic Preservation Act. CAR proposed that monitoring of the construction activities and documenting any exposed portions of the acequia would mitigate the impact.

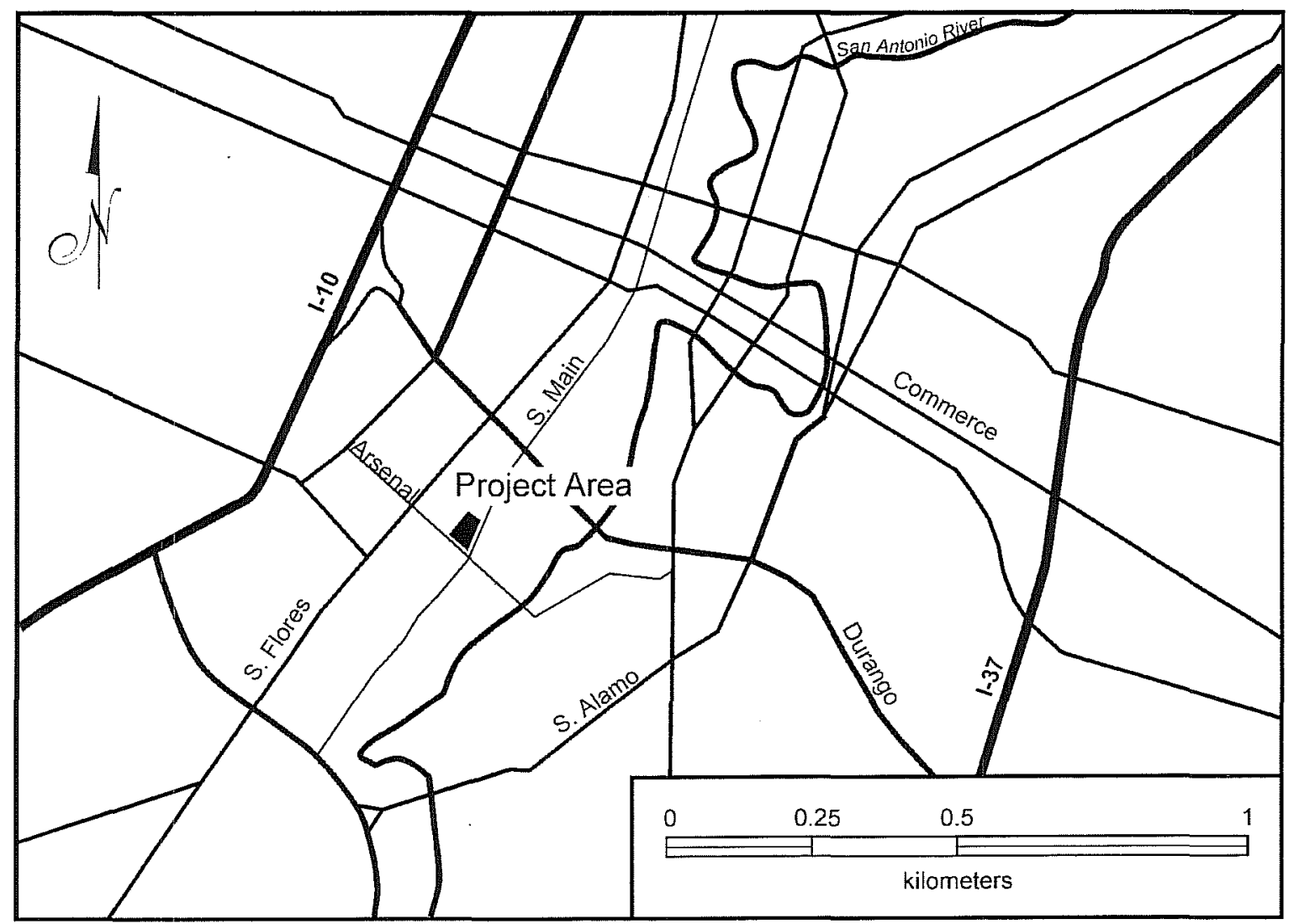

Figure 1. Project location map. 


\section{Previous Archaeological Investigations}

The San Pedro acequia was studied by CAR in 1978 with the original investigation of the portion of the United States Arsenal property that is now under the jurisdiction of the San Antonio Parks and Recreation Department, known as the "Commander House" (41BX351). At that time a portion of the stone-lined acequia was examined and documented (Fox 1978). In 1981 CAR investigated several portions of the San Pedro Acequia approximately three city blocks to the south of the present investigation and found both lined and unlined sections of the channel (Frkuska 1981). Five years later, three sections of the acequia near its source, San Pedro Springs, were investigated when they were exposed by construction of a parking lot (Cox 1986). An additional section in this vicinity was examined in 1993 (Cox 1993). City improvements for the small street to the north of San Fernando Cathedral on Main Plaza in 1995 revealed a section of the stonelined acequia as well as the domed covering applied when the system was converted to storm drainage (Cox 1995). Prior to approval for the construction of the present project, the area was tested by the U.S. Army Corps of Engineers. The acequia was located and recommendations for its preservation resulted in an alternative boundary selection to lessen the impact upon this historic resource (Patterson 1997).

\section{History of the San Pedro Acequia}

The origins of the San Pedro Acequia can be traced back to the earliest days of San Antonio. On March 9, 1731, fifty-six Canary Islanders arrived at the presidio to form the nucleus of the Villa of San Fernando de Bexar, the first civil settlement of Texas. Viceroy Casafuente had ordered that the newcomers be greeted and housed in the presidio until the villa was established a "gunshot's distance . . . to the west of the presidio (de Aviles 1731)." The captain of the presidio, Juan Antonio Pérez de Alamazán, decided against this location due to the inability to irrigate the site. He selected instead the land immediately east of the presidio (now Main Plaza), and delayed the laying out of the villa until after the planting season, selecting "land subject to irrigation" as temporary fields for the Islanders (Alamazán 1731). For the land to be granted to the settlers, Alamazán had selected the fertile area to the south of the villa between the river and the creek down to the confluence of the streams (Alamazán 1731). Each family was consigned a plot sufficient to plant their crops.

The banks of the two streams were deep enough in this area to make irrigation difficult; therefore, an acequia was envisioned beginning at San Pedro Springs, proceeding southward between the water courses, and returning to the river just prior to the confluence. This design presented two distinct advantages: first, it could service the Barrio del Norte, the presidio, the villa, and the Islanders' fields; secondly, by following the high ground between the two water courses, it could irrigate lands on both sides, in contrast to the other acequias which only watered the lands toward the river. Construction dates are not recorded; it is logical to assume, however, that the acequia was initiated soon after assignment of the land. On January 11,1734 , by order of the viceroy, the lands were resurveyed and official title was granted to the Islanders. In all probability, the acequia was in operation by this time (Leal, J. O. "Division of the Lands of the Canary Islanders in San Antonio," 1986. Bexar County Archives [BCA], Office of the County Clerk, Bexar County, Bexar County Courthouse, San Antonio, Texas).

With the completion of the San Pedro Acequia, the entire basin between the creek and the river could now be irrigated from the area of the springs to the confluence of the two streams. The channel was approximately four miles in length and watered approximately 400 acres below the villa, the new lands of the Islanders and other citizens. This channel was destined to serve the community as irrigation water, as well as the primary source of drinking water, for well over a century.

On February 2, 1852, Alderman Lockhart presented a resolution to the council proposing action to be taken on the acequia, the first major revision to the system since its construction some 120 years earlier. The motion stated: 
Resolved that the mayor be and is hereby authorized to receive proposals for constructing a ditch across the Main Plaza in line of the present dilapidated one of the following dimensions, three feet wide at the bottom and four feet at the top, solid masonry of stone laid in sand and lime. Wall eighteen inches thick to be paved at the bottom with flat stone. Excavated and completed, the surplus dirt to be deposited in the old or present ditch under the supervision of the mayor and Improvements Committee [City Council Minutes (CCM), Office of the City Clerk, City Hall, San Antonio, Texas, Volume B, p. 158].

This is the first instance of the complete stone lining that would be undertaken on the various channels throughout the downtown area. This lining is yet in place in many areas of the city under our streets and many buildings. Those short sections of the acequia, now exposed at several locations throughout the city, exhibit the ashlar-dressed stone work of this period.

In 1859 land to the south of Main Plaza was granted to serve as an arsenal for the U. S. Army to furnish arms and munitions to the frontier forts of Texas. During the Civil War, the 21-acre reservation was occupied by Confederate forces, and returned to the federal government after that conflict (Long 1996:799). Portions of the structures were built around and atop the stone walls of the acequia.

In February 1881, the Ditch Committee recommended "converting the San Pedro ditch through the Arsenal property to a straight line and erection of a bridge on Arsenal Street," all at a cost of $\$ 180.00$ (CCM, E:311). In July 1883 a special committee was assigned to evaluate the need for irrigation ditches in regard to their cost effectiveness. Alderman Lockwood's report to City Council stated, "the city expending, for 411 persons, not less than $\$ 4000$ per year, including salaries of ditch commissioners, repairing of bridges, cleaning of ditches \&c. As near as we could ascertain, 29 persons out of the 411 are engaged in the business of raising vegetables for sale to the public" (San Antonio Express [SAE] 18 July 1883). However, the committee agreed that some system of draining excess water from the city was necessary, and the acequias did to some effect fulfill that function, but they felt that a sewerage system designed strictly for that purpose might be more effective ( $S A E 18$ July 1883). In November 1904, Alderman Lambert proposed that the South Flores branch of the San Pedro Acequia, and the truck garden tributary, be abandoned and irrigation water be supplied by contract from the U.S. Arsenal. He suggested that the waters of this ditch should be diverted into the San Pedro Creek to augment the flow. Action was referred to the committee on ditches (SAE, 8 November 1904). In December 1909, the venerable waterway was to be dealt the fate of the other acequias that had once watered the city. "The picturesque old North Flores Street ditch which irrigated the gardens of the earliest settlers from Spain and France who helped win San Antonio from sterility and the Indians must go" ( $S A E$, 3 December 1909). The Board of Health noted that it no longer served its purpose and served only as a "menace to the public health" and ordered it closed (SAE, 3 December 1909). However, the council was beset by petition from the citizens requesting both that the waterway be closed and remain open. Finally, in September 1912 the council enacted ordinance JV-10 stating: "That said San Pedro Ditch be, and the same is hereby closed" (CCM, V:39).

\section{Monitoring}

Monitoring for the construction of the HEB parking lot began on the morning of October 6, 1997, upon notification by personnel of Gates Construction that work was beginning in the vicinity of the reported route of the old channel. The area was examined and no visible signs of the acequia were evident with the exception of traces revealed by sparse growth of lawn in some areas to the north of the construction area, in the area tested by Patterson (1997). Work at that time was restricted to clearing of the area to the north of the existing two-story stone structure $(\mathrm{P}-8)$ to be surrounded by the proposed parking lot. Later in the morning, work was begun to clear the existing asphalt to the west and south of the structure. This revealed a compacted base of gravel extending to a depth of approximately 12 inches over the entire area.

By mid-afternoon, the company installing the new fence around the proposed parking lot arrived and 


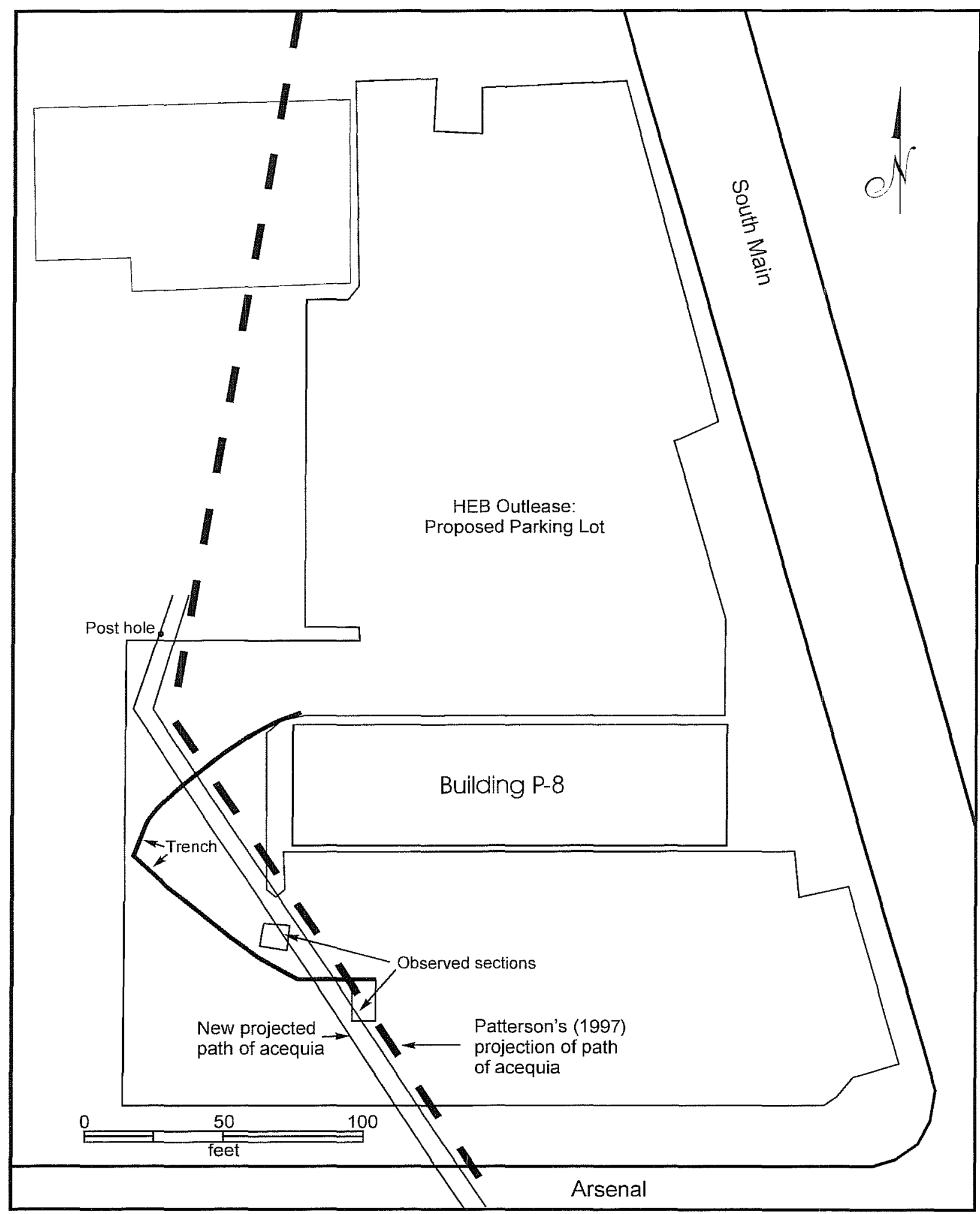

Figure 2. Map of project area with projected path of the San Pedro Acequia. 
began drilling holes to set the post. The first hole drilled, to the northeast of building P-8, struck a limestone block of the west wall of the acequia (Figure 2). Examination of the hole revealed that the top stone of the acequia was four inches below the present surface and extended to the depth of the hole, some 24 inches. None of the other postholes encountered the acequia.

The following day, October 7, the construction crew was engaged in cleaning up the loosened asphalt, surface clearing, and removing portions of the old railroad spur line on the south side of Building P-8, all well clear of the path of the acequia. The company selected to install the electrical lines, Eldridge Electrical, arrived and the project was discussed and personnel were briefed on the concerns for the acequia. The time for their excavation was not determined because of the need to schedule a rock saw to perform the excavation. Since no further monitoring was required, observation was terminated at midday.

Further monitoring was delayed until October 13 when the Ditch Witch-riding rock saw was available. Trench excavation began at the fence line to the west of Building P-8 and proceeded toward the southeast. The acequia was exposed $31.5 \mathrm{ft}$ south of the building (Observed Section 1, Figure 2). The eastern wall was badly disturbed at this point but was still easily discerned. The western wall was fully intact three inches below the compacted gravel base. The acequia was five feet wide at this point through the angled saw cut. The cut extended to a depth of 26 inches. No artifacts were observed in this disturbance.

The second portion of the trench was cut from the fence line toward the northwest corner of Building P-8. The acequia was not detected with this excavation; however, fragments of extruded red-clay building tiles (ca. 19201930) were observed in the material excavated in the area of the proposed path of the acequia. At the end of the trench, at the corner of Building P-8, a water line was cut and the excavation flooded, precluding further examination until the water drained. The 26inch-deep cut revealed no signs of the acequia even after the walls were cleaned.

The following day, a cut from the southwest corner of Building P-8 severed a telephone cable, making it necessary to clear an area to the east of the first cut where the acequia was observed. This revealed a fully intact section of the east wall (Observed Section 2). It was constructed of quarried limestone, ashler dressed, with a rough exterior exposed by the clearing (Figure 3). The blocks averaged $12 \times 28 \times 6$ inches in size.

On October 21, the contractor called to report that a section of the acequia had been exposed by further base preparation. The area, slightly northwest of Observed Section 1, was covered until the archaeologist could arrive on the site. Once the gravel base was removed and the area uncovered, the western wall of the acequia (Oserved Section 3) was measured and photographed. Based upon the observed sections and the path of the acequia to the south of Arsenal Street (Figure 4), as documented by the 1904 Sanborn Insurance maps, the proposed path of the acequia as plotted by Patterson (1997) was corrected (Figure 2). Monitoring was terminated at that point since further construction would have no impact on the acequia.

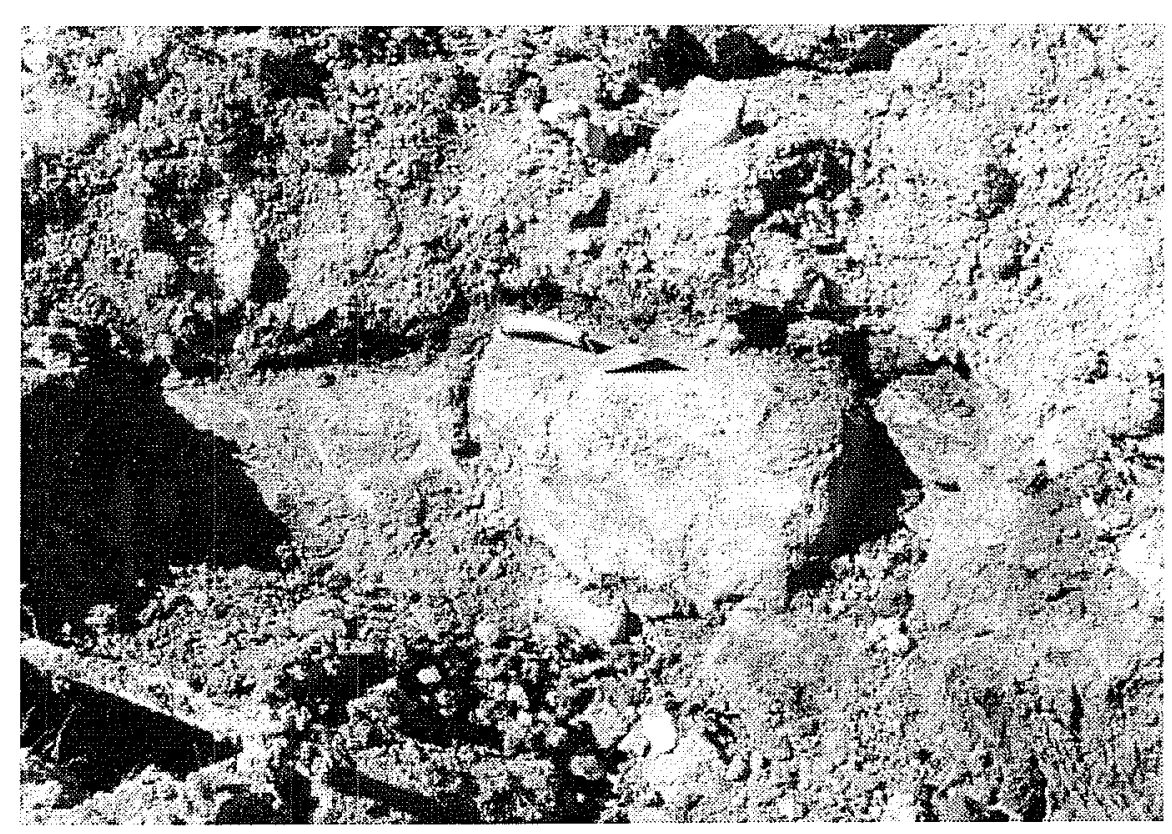

Figure 3. Photograph of a section of the east wall of the acequia. 


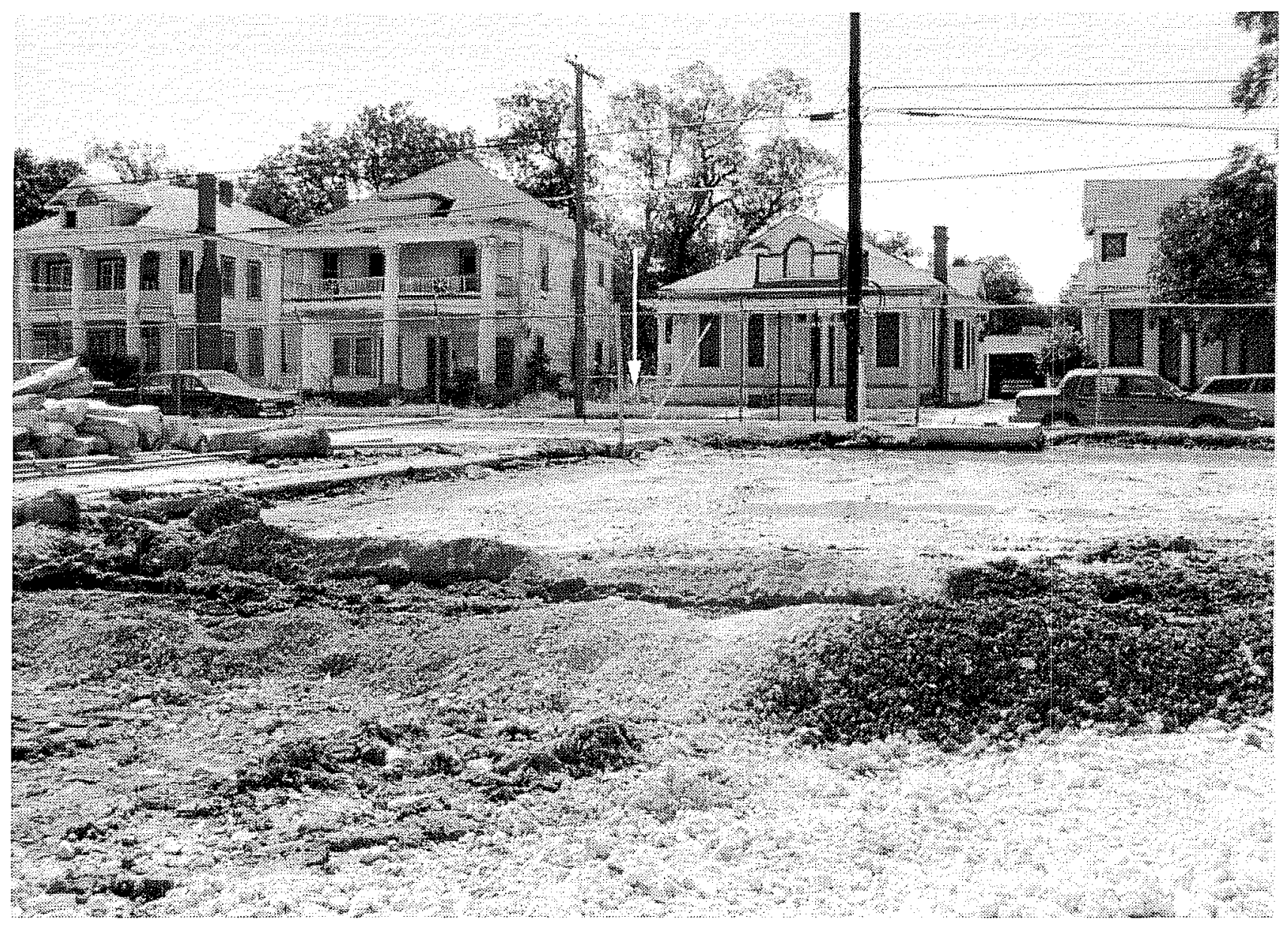

Figure 4. Project area looking south toward Arsenal Street. The path of the acequia across Arsenal is marked with the white arrow.

\section{Conclusions and Recommendations}

This monitoring of the San Pedro Acequia has served the purpose of further documenting the nature of the construction and course of the channel beyond the known path in this area (Figure 4) and the section excavated farther to the south at the site of the 1981 study (Frkuska 1981). The section observed during this monitoring is probably the result of the construction of 1881 to straighten the acequia as recommended by the Ditch Commissioner to the City Council (CCM, $\mathrm{E}: 311$ ). CAR recommends that the monitoring-level investigations have mitigated the impacts to the acequia. Since all further work for this project is to be surface in nature, no further archaeological investigations are recommended at this time. However, should future work be undertaken in further developments additional monitoring should be considered. 


\section{References Cited}

Cox, I. W.

1986 Excavations of Portions of the San Pedro Acequia (41BX337) and a Search for the Arocha Acequia, San Antonio, Texas. Archaeological Survey Report, No. 161. Center for Archaeological Research, The University of Texas at San Antonio.

1993 Excavation of a Portion of the San Pedro Acequia (41 BX 337) VIA Metropolitan Transit System Parking Lot, San Antonio, Texas. Archaeological Survey Report, No, 219. Center for Archaeological Research, The University of Texas at San Antonio.

1995 Documentation of the San Pedro Acequia (41 BX 337) at Treviño Street, San Antonio, Texas. Archaeological Survey Report, No, 230.Center for Archaeological Research, The University of Texas at San Antonio.

de Alamazán, J. A. P.

1731 Report of the Survey of the Original Town Tract of San Fernando de Béxar, 1731. Spanish Materials from Various Sources, Barker History Center, Austin, Texas.

de Aviles, A.

1731 Carpeta de Correspondencia de la Provincicas Internas por los años de 1726 a 1731. Archivo General de la Nación de México, Volume 236:28. Microfilm, Nettie Lee Benson Latin American Collection, The Univeristy of Texas at Austin.

Fox, A. A.

1978 Archaeological Investigations of Portions of the San Pedro and Alazan Acequias in San Antonio, Texas. Archaeological Survey Report, No 49. Center for Archaeological Research, The University of Texas at San Antonio.

Frkuska, A. J. Jr.

1981 Archaeological Investigations at the San Pedro Acequia, San Antonio, Texas. Archaeological Survey Report, No. 103. Center for Archaeological Research, The University of Texas at San Antonio.

Long, C.

1996 San Antonio Arsenal. In The New Handbook of Texas, edited by R. Tyler, 5:799. The Texas State Historical Association, Austin.

Patterson, P. E.

1997 Phase I Archaeological Investigation of the Proposed Outlease at the Federal Center, San Antonio, Texas. U. S. Army Corps of Engineers, Fort Worth District.

San Antonio Express [SAE]

1883 City Council. 18 July.

1904 Aldermen Discuss Fire Protection. 8 November.

1909 Picturesque North Flores Ditch Must Go. 3 December. 


